\title{
Influence of Weather Parameters on Development of Maydis Leaf Blight of Maize Caused by Bipolaris maydis (Nisikado Shoemaker)
}

\author{
S.V. Goudar ${ }^{1 *}$ and S.I. Harlapur ${ }^{2}$ \\ Department of Plant Pathology, College of Agriculture, Dharwad \\ University of Agricultural Sciences, Dharwad - 580 005, Karnataka (India) \\ *Corresponding author
}

\section{Keywords}

Temperature,

Relative humidity,

Rainfall, Number of rainy days, $\mathrm{PDI}$, Maydis leaf blight

Article Info

Accepted:

18 January 2019

Available Online:

10 February 2019

\section{A B S T R A C T}

A field experiment was conducted at Main Agriculture Research Station, University of Agriculture Sciences, Dharwad, to study the disease development in relation to weather parameters, which clearly depicts the relationship between the weather factors like temperature, relative humidity, rainfall and number of rainy days with the development of the maydis leaf blight of maize. Observations were taken from 31st standard week to 39th standard weeks at weekly interval. The PDI was lowest during 31 st standard week (8.34 $\%$ ) and increased throughout the cropping period. It was peak during last stage that is 39th standard week $(80.07 \%)$. During cropping period maximum temperature ranged from $25^{\circ} \mathrm{C}$ (31st standard week) to $29.4^{\circ} \mathrm{C}$ (35th standard week), minimum temperature from $19.3^{\circ} \mathrm{C}$ (35th standard week) to $21^{\circ} \mathrm{C}$ (37th standard week), relative humidity (morning) from 91 per cent (35th standard week) to 95 per cent (38th standard week) and relative humidity (evening) from 63 per cent (35th standard week) to 85 per cent (31st standard week). Cumulative weekly rainfall ranged from $59.60 \mathrm{~mm}$ (31st standard week) to 237.80 $\mathrm{mm}$ (39th standard week). No of rainy days ranged from 1 (32nd standard week) to 6 (37th standard week). With respect to weather studies the per cent disease index at weekly intervals were calculated. This was progressing at linear rate as the age of the plant was increasing. Maximum temperature $(r=0.40)$, minimum temperature $(r=0.03)$ were not significantly positively correlated with PDI. Morning relative humidity $(r=-0.03)$, evening relative humidity $(r=-0.45)$ and number of rainy days $(r=-0.12)$ were not significantly negatively correlated with PDI. While, the rainfall showed a highly significant positive correlation with PDI.

\section{Introduction}

Maize is grown throughout the world under a wide range of climatic conditions. In India, maize is an important cereal crop next to rice, wheat and sorghum. It is mainly grown in Karnataka, Andhra Pradesh, Maharashtra,
Uttar Pradesh, Bihar, Rajasthan, Madhya Pradesh and Punjab. Maydis leaf blight of maize (Zea mays L.) caused by Bipolaris maydis (Nisikado) Shoemaker (Teliomorph: Cochliobolus heterostrophus) covers the widest geographical area and it is considered as a major foliar pathogen (Ullstrup, 1972 and 
Tatum 1971). In India, the disease was first reported by Munjal and Kapoor (1960) from Malda (West Bengal). The maydis leaf blight injures or kills the leaf tissues and thereby reduces the area of chlorophyll which involved in photosynthesis. If considerable leaf area is killed, then vigour and yields are reduced drastically. If much of the green area is killed starch formation is restricted and the kernels become chaffy. The blighted leaves are not suitable for fodder because of the lowered nutrition value. In northern Karnataka, the disease is becoming important in recent years and there is no systematic information available with respect to maydis leaf blight.

\section{Materials and Methods}

The influence of weather factors like temperature (maximum and minimum), relative humidity (morning and evening), rain fall and number of rainy days on the development of maydis leaf blight was studied at Main Agriculture Research Station, University of Agriculture Sciences, Dharwad. This study was undertaken. Highly susceptible hybrid $900 \mathrm{M}$ was sown in $10 \times$ $10 \mathrm{~m}$ block with $60 \times 20 \mathrm{~cm}$ spacing and the crop was raised with the recommended agronomic practices. The observations were made on disease incidence and severity starting from first day of its appearance and till the physiological maturity of crop. It was correlated with weather parameters by simple correlation. The meteorological observations at Main Agriculture Research Station, UAS, Dharwad were used for this experiment.

The present investigation of maydis leaf blight of maize was undertaken at Main Agriculture Research Station, UAS Dharwad. The mean weekly rainfall at Dharwad was $26.43 \mathrm{~mm}$ during the experimental period. The mean minimum and maximum temperature during this cropping period ranged from $20.05^{0} \mathrm{C}$ to $27.16^{0} \mathrm{C}$ respectively. The mean relative humidity ranged from 75.78 to 93.89 per cent was favourable for the disease development. In general the environmental conditions were favourable for the outbreak of the disease in 2013. Hence maydis blight was severe.

\section{Results and Discussion}

\section{Disease development}

In the present investigation, disease development in relation to weather parameters were studied as described in materials and methods. This study clearly depicts the relationship between the weather factors like temperature, relative humidity, rainfall and number of rainy days with the development of the maydis leaf blight of maize. Observations were taken from 31st standard week to 39th standard weeks at weekly interval. The data presented in Table 3. The PDI was lowest during 31st standard week $(8.34 \%)$ and increased throughout the cropping period. It was peak during last stage that is 39th standard week (80.07\%). During cropping period maximum temperature ranged from $25^{\circ} \mathrm{C}$ (31st standard week) to $29.4^{\circ} \mathrm{C}$ (35th standard week), minimum temperature from $19.3^{\circ} \mathrm{C}$ (35th standard week) to $21^{\circ} \mathrm{C}$ (37th standard week), relative humidity (morning) from91 per cent (35th standard week) to 95 per cent (38th standard week) and relative humidity (evening) from 63 per cent (35th standard week) to 85 per cent (31st standard week). Cumulative weekly rainfall ranged from $59.60 \mathrm{~mm}$ (31st standard week) to $237.80 \mathrm{~mm}$ (39th standard week). No of rainy days ranged from 1 (32nd standard week) to6 (37th standard week) (Table 1).

With respect to weather studies the per cent disease index at weekly intervals were calculated. This was progressing at linear rate as the age of the plant was increasing. 
Table.1 Influence of weather parameters on the development of maydis leaf blight

\begin{tabular}{|c|c|c|c|c|c|c|c|c|c|}
\hline \multirow{2}{*}{$\begin{array}{l}\text { Standard } \\
\text { week No. }\end{array}$} & \multirow[t]{2}{*}{ Month and date } & \multirow{2}{*}{$\begin{array}{l}\text { Age of the } \\
\text { crop } \\
\text { (Days) }\end{array}$} & \multirow{2}{*}{$\begin{array}{l}\text { Per cent } \\
\text { disease } \\
\text { index }\end{array}$} & \multicolumn{2}{|c|}{ Temperature $\left({ }^{\circ} \mathrm{C}\right)$} & \multicolumn{2}{|c|}{ Relative humidity (\%) } & \multirow{2}{*}{$\begin{array}{l}\text { Cumulative } \\
\text { Rainfall } \\
\text { (mm) }\end{array}$} & \multirow{2}{*}{$\begin{array}{l}\text { No. of rainy } \\
\text { days }\end{array}$} \\
\hline & & & & $\underset{\mathrm{m}}{\operatorname{Maximu}}$ & Minimum & Morning & Evening & & \\
\hline 31 & August $1-8$ & 36 & $\begin{array}{c}8.90 \\
(17.33)^{*}\end{array}$ & 25.0 & 20.1 & 95 & 85 & 59.6 & 6 \\
\hline 32 & August $9-16$ & 44 & $\begin{array}{l}17.11 \\
(24.33)\end{array}$ & 27.2 & 20.0 & 94 & 78 & 78.0 & 1 \\
\hline 33 & August $17-24$ & 52 & $\begin{array}{c}21.73 \\
(27.77)\end{array}$ & 26.3 & 20.5 & 95 & 79 & 90.0 & 1 \\
\hline 34 & August 25 - September 1 & 60 & $\begin{array}{c}36.37 \\
(37.11)\end{array}$ & 26.3 & 19.5 & 92 & 79 & 101.6 & 3 \\
\hline 35 & September $2-9$ & 68 & $\begin{array}{c}43.91 \\
(41.52)\end{array}$ & 29.4 & 19.3 & 91 & 63 & 109.6 & 1 \\
\hline 36 & September $10-17$ & 76 & $\begin{array}{c}51.21 \\
(45.72)\end{array}$ & 28.6 & 20.0 & 94 & 73 & 119.0 & 2 \\
\hline 37 & September $18-25$ & 84 & $\begin{array}{c}61.56 \\
(51.72)\end{array}$ & 28.0 & 21.0 & 95 & 73 & 216.0 & 6 \\
\hline 38 & September 26 - October 3 & 92 & $\begin{array}{c}68.44 \\
(55.87)\end{array}$ & 27.2 & 20.4 & 95 & 75 & 231.4 & 3 \\
\hline 39 & October $4-11$ & 100 & $\begin{array}{c}80.65 \\
(63.97)\end{array}$ & 26.5 & 19.7 & 94 & 77 & 237.8 & 1 \\
\hline
\end{tabular}

* Figures in parenthesis are arcsine values 
Table. 2 Correlation between per cent disease index of maydis leaf blight of maize in relation to weather parameters

\begin{tabular}{|c|c|c|c|c|c|c|c|}
\hline Parameters & $\mathbf{Y}$ & $\mathbf{X}_{1}$ & $\mathbf{X}_{2}$ & $\mathbf{X}_{3}$ & $\mathbf{X}_{4}$ & $\mathbf{X}_{5}$ & $X_{6}$ \\
\hline $\begin{array}{c}\text { Y } \\
\text { PDI }\end{array}$ & 1.000 & 0.406 & 0.035 & -0.035 & -0.459 & $0.926^{*}$ & -0.123 \\
\hline $\begin{array}{c}\mathrm{X}_{1} \\
\text { Maximum temperature }\left({ }^{0} \mathrm{C}\right)\end{array}$ & 0.406 & 1.000 & -0.127 & -0.457 & $-0.946^{*}$ & 0.201 & -0.310 \\
\hline $\begin{array}{c}\mathrm{X}_{2} \\
\text { Minimum temperature }\left({ }^{0} \mathrm{C}\right)\end{array}$ & 0.035 & -0.127 & 1.000 & $0.845^{*}$ & 0.258 & 0.310 & 0.518 \\
\hline $\begin{array}{c}\mathrm{X}_{3} \\
\text { Relative humidity (morning) } \\
(\%)\end{array}$ & -0.035 & -0.457 & 0.845 & 1.000 & 0.581 & 0.244 & 0.404 \\
\hline$\underset{(\%)}{\mathrm{X}_{4}} \underset{(\mathrm{O})}{\text { Relative humidity (evening) }}$ & -0.459 & -0.946 & 0.258 & 0.581 & 1.000 & -0.258 & 0.348 \\
\hline $\begin{array}{c}\mathbf{X}_{5} \\
\text { Rainfall (mm) }\end{array}$ & 0.926 & 0.201 & 0.310 & 0.244 & -0.258 & 1.000 & 0.076 \\
\hline $\begin{array}{c}\mathrm{X}_{6} \\
\text { No. of rainy days }\end{array}$ & -0.123 & -0.310 & 0.518 & 0.404 & 0.348 & 0.076 & 1.000 \\
\hline
\end{tabular}

*Significant at $\mathrm{P}=0.05$

Table.2a Correlation coefficient (r) for maydis leaf blight severity with weather variables

\begin{tabular}{|l|c|}
\hline \multicolumn{1}{|c|}{ Weather parameters } & Correlation Coefficient (r) \\
\hline Maximum temperature $\left({ }^{\mathbf{0}} \mathbf{C}\right)$ & 0.40 \\
\hline Minimum temperature $\left({ }^{\mathbf{0}} \mathbf{C}\right)$ & 0.03 \\
\hline Relative humidity (morning) $(\boldsymbol{\%})$ & -0.03 \\
\hline Relative humidity (evening) $(\boldsymbol{\%})$ & -0.45 \\
\hline Rainfall (mm) & $0.92^{*}$ \\
\hline No. of rainy days & -0.12 \\
\hline
\end{tabular}

*Significant at $\mathrm{P}=0.05$ 
Table.3 Multiple linear regression between per cent disease index of maydis leaf blight of maize in relation to weather parameters

\begin{tabular}{|c|c|c|c|c|c|c|}
\hline Parameter & $\begin{array}{c}\mathrm{X}_{1} \\
\text { Maximum } \\
\text { temperature }\left({ }^{0} \mathrm{C}\right)\end{array}$ & $\begin{array}{c}\mathrm{X}_{2} \\
\text { Minimum } \\
\text { temperature }\left({ }^{0} \mathrm{C}\right)\end{array}$ & $\begin{array}{c}\mathbf{X}_{3} \\
\text { Relative humidity } \\
\text { (morning) }(\%)\end{array}$ & $\begin{array}{c}\mathrm{X}_{4} \\
\begin{array}{c}\text { Relative humidity } \\
\text { (evening) }(\%)\end{array}\end{array}$ & $\begin{array}{c}\mathrm{X}_{5} \\
\text { Rainfall (mm) }\end{array}$ & $\begin{array}{c}\mathrm{X}_{6} \\
\begin{array}{c}\text { No. of rainy } \\
\text { days }\end{array}\end{array}$ \\
\hline $\begin{array}{c}\beta- \\
\text { Value (RC) }\end{array}$ & 5.199 & -6.289 & -0.861 & 0.886 & 0.222 & -0.309 \\
\hline SE of $\beta$ (r) & 5.218 & 9.861 & 4.224 & 1.399 & 1.032 & 1.262 \\
\hline Intercept & \multicolumn{6}{|c|}{9.825} \\
\hline $\mathbf{R}^{2}$ value & \multicolumn{6}{|c|}{0.96} \\
\hline \multicolumn{7}{|c|}{ Multiple linear regression equation $\quad Y=a+\beta 1 X_{1}+\beta 2 X_{2}+\beta 3 X_{3}+\beta 4 X_{4}+\beta 5 X_{5}+\beta 6 X_{6}$} \\
\hline \multicolumn{7}{|c|}{$Y=9.825+5.199 X_{1}-6.289 X_{2}-0.861 X_{3}+0.886 X_{4}+0.222 X_{5}-0.309 X_{6}$} \\
\hline
\end{tabular}


Susceptibility of maize plants increased with age so that older leaves were more susceptible than younger leaves. Maximum temperature ( $\mathrm{r}$ $=0.40)$, minimum temperature $(r=0.03)$ were not significantly positively correlated with PDI. Morning relative humidity $(r=-0.03)$, evening relative humidity $(\mathrm{r}=-0.45)$ and number of rainy days $(r=-0.12)$ were not significantly negatively correlated with PDI (Table 2 and 2a). Similarly Wallin and Loonan (1977) reported longer dew period up to 48 hour at higher temperatures of $28^{\circ} \mathrm{C}$ resulted in greatest spore production.

While, the rainfall showed a highly significant positive correlation with PDI. These results were in accordance with Sharma and Mishra (1988). Similarly, Harlapur et al., (2000) reported that high rainfall coupled with low temperature during September increased the incidence of TLB and caused significant yield loss. Pandurangegowda et al., (1994) also observed that the incidence of TLB of maize increased from June to October. Meteorological factors like temperature $\left(22-38^{\circ} \mathrm{C}\right)$, relative humidity (72-98\%) and rainfall (134-165 mm) have shown highly significant correlation with disease intensity. The multiple regression equation developed for 2013 was $\mathrm{Y}=9.825$ $+5.199 \mathrm{X} 1-6.289 \mathrm{X} 2-0.861 \mathrm{X} 3+0.886 \mathrm{X} 4+$ $0.222 \times 5-0.309 \times 6$ with $\mathrm{R}^{2}=0.96$ i.e., the weather parameters put together influence PDI to the extent of 80.65 per cent (Table 3). Pandurangegowda et al., (1989) studied the incidence of E. turcicum on the susceptible cv. CM-202 sown at fortnightly intervals and reported that meteorological factors like temperature 22 to $38^{\circ} \mathrm{C}$, relative humidity 72 to 98 per cent and rainfall 134 to $165 \mathrm{~mm}$ were correlated with increased disease intensity. In
Georgia, Russia, the most favourable conditions for development of maize leaf blight were 22 to $25^{\circ} \mathrm{C}$ temperature and 75 to 90 per cent relative humidity (Khatri, 1993).

\section{References}

Harlapur, S. I., Wali, M, C., Anahosur, K. H. and Muralikrishna, S., 2000, A report survey and surveillance of maize diseases in North Karnataka. Karnataka J. Agric. Sci., 13 (3): 750-751.

Munjal, R. L. and Kapoor, J. N., 1960, Some unrecorded diseases of sorghum and maize from India. Curr. Sci., 29: 442-443.

Pandurangegowda, K. T., Sangamlal, Meenashekhar, Mani, V. P. and Singh, W. W., 1994, Additional source of resistance in maize to Exserohilum turcicum. Indian J. of Agric. Sci., 64: 498-500.

Pandurangegowda, K.T., Jayaramagowda B. and Rajashekharaiah, 1989, Variability in the incidence of turcicum leaf blight of maize in southern Karnataka. Curr. Res., 18: 115-116.

Sharma, J. P. and Mishra, B., 1988, Effect of spray schedule of mancozeb on turcicum leaf blight and impact on grain yield in maize. Indian J. Plant Prot., 16:189-193.

Tatum, L. A., 1971, The southern leaf blight epidemic. Sci., 117: 1113-1116.

Ullstrup, A. J., 1972, The impact of the southern corn leaf blight. Annu Rew Phytopath., 10: 37-50.

Wallin, J. R. and Loonan, D. V., 1977, Temperature and humidity associated with sporulation of Helminthosporium maydisrace T. Phytopathol., 67: 13701372.

\section{How to cite this article:}

Goudar, S.V. and Harlapur, S.I. 2019. Influence of Weather Parameters on Development of Maydis Leaf Blight of Maize Caused by Bipolaris maydis (Nisikado Shoemaker). Int.J.Curr.Microbiol.App.Sci. 8(02): 2240-2245. doi: https://doi.org/10.20546/ijcmas.2019.802.259 